\title{
Establishment and Implementation of Japanese Training Project Based on Concept of CDIO---By the Example of Training Project "Simulation and Display of Japanese Conversational Scene"
}

\author{
Qiang $\mathrm{Qu}^{1}$, a and Fang Sun ${ }^{2, \mathrm{~b}}$ \\ ${ }^{1}$ Applied Foreign Language Department of Chengdu Neusoft University No.1 Dongruan Road, \\ Qingchengshan, Dujiangyan, Chengdu, Sichuan 611844, P.R.China \\ ${ }^{2}$ Applied Foreign Language Department of Chengdu Neusoft University No.1 Dongruan Road, \\ Qingchengshan, Dujiangyan, Chengdu, Sichuan 611844, P.R.China \\ aquqiang@nsu.edu.cn, bsunfang@nsu.edu.cn
}

Keywords: CDIO; Japanese major; Practice project; Talent cultivation

\begin{abstract}
To analyze how the engineering education concept - CDIO is applied to Japanese practice project based on the investigation of the social needs, the researcher of this paper carefully select, construct and implement the training project - "Simulation and Display of Japanese Conversational Scene". This paper not only summarizes the project's outcomes and existing problems but also provides countermeasures. It helps to promote the cultivation of Japanese majors in application oriented universities.
\end{abstract}

\section{Introduction}

Compared with research-based universities, application oriented universities are educational organizations for social practical needs and aim to cultivate applied talents whose abilities should be closely connected with daily work and life.[1] Therefore, the cultivation aims of Japanese majors in an application oriented universities should be developing students' practical abilities and embody their comprehensive abilities. By the example of the training project SDJCS - "Simulation and Display of Japanese Conversational Scene" in Chengdu Neusoft University, this paper will analyze how the cultivation of Japanese majors is established and implemented based on CDIO.

\section{Conceive and Design}

The Concept of CDIO. CDIO was first put forward in engineering education and aimed to cultivate students in modern work teams to conceive - design - implement - operate complicated and advanced products, processes or systems.[2] This education mode emphasizes engineering education should accord with the requirements for engineers put forward by modern society, and it combines teaching with the complete period of a production operation. Thus it has been highly praised by engineering education. Furthermore, the concept of CDIO has also been used in other fields such as foreign language teaching in Chengdu Neusoft University. The core concept of CDIO is to emphasize student-centered education and cultivate the abilities of self-learning, practical learning, analyzing and solving problems, teamwork and communication.[3]

Selection of Project. Education should focus on long-term value and support sustainable vocational learning.[4] Language stems from daily life, so language teaching should also focus on daily communication. The simulation of daily conversational scene can embody students' applied abilities. In addition, "project-centered learning" is new mode of class learning, which replaced the traditional teacher-centered teaching mode. It focuses on transdisciplinary and student-centered learning activities.[5] Following these principles the educators in Chengdu Neusoft University carefully selected the training project for the freshmen. The following factors are the key considerations for the selection:

A lot of research datum showed that modern Japanese major related positions needed Japanese IT translation, professional Japanese data analysis, Japanese business management, contact and 
cooperation with Japan, etc.[6] It can be seen that spoken language plays an important part in the above positions. Therefore, the course related to daily conversation should be offered in the first year as a basis of spoken language teaching.

What's more, the above position also requires students to master the skills of computers and IT and to have team spirit.

Based on the concept of CDIO, teaching should persist in the principle of "Integration".[7] Teaching should combine different courses such as Basic Japanese, Spoken Japanese, Japanese Listening, Computer Basis, Multimedia Technology, etc. A comprehensive project should effectively combine those courses and then helps to cultivate students applied abilities.

A carrier is needed to integrate those courses. The project SDJCS makes students summarize and apply what they have leant before, and meanwhile lay a foundation for later courses. Through the project student can not only improve their spoken Japanese but also learn team spirit and computer application.

\section{Implementation and Operation}

The Goal of Project. The project SDJCS converted the basic knowledge students acquired in different courses into practical skills. Five conversational scenes were designed for this project: Meeting for the First Time, Shopping, Telephone Communication, Seeing a Doctor and Travelling. Through compiling, practicing and demonstrating those scenes students learnt to master Japanese pronunciation, practice the skills of listening, speaking, reading and writing, and understand the management of a project, team spirit and using multimedia. Meanwhile, they also learnt to integrate all those skills and knowledge to successfully accomplish the project, and what they learnt in this project would in turn lay a good foundation for future learning.

Content of Project. This project was set in the third term of the first academic year, and totally has 80 hours. It required students to simulate and display a Japanese conversational scene in a team of four or five persons. Their projects should integrate what they have learnt in the first two terms. Each student had a different job in the project. Teachers were in charge of instructing students to make a project schedule, practice listening and speaking skills, compile and practice conversation, shoot and improve their videos, and finally demonstrate their products in teams. At the end of the third term teachers made comments on students' products and helped them to find out their strengths and weaknesses, which would improve their future study. The project was divided into seven units, and each should finish a stage goal as Table 1 shows: 
Table 1 Seven-Unit Projects

\begin{tabular}{|c|c|c|}
\hline Units & Tasks & Goals \\
\hline $\begin{array}{l}\text { Project Startup }(2 \\
\text { hours })\end{array}$ & $\begin{array}{l}\text { 1. Introduce project. } \\
\text { 2. Make a team. }\end{array}$ & $\begin{array}{l}\text { 1. Learn the process of the whole } \\
\text { project. } \\
\text { 2. Make an efficient team. } \\
\text { 3. Assign instructors. }\end{array}$ \\
\hline $\begin{array}{l}\text { Project Planning ( } 2 \\
\text { hours) }\end{array}$ & $\begin{array}{l}\text { 1. Divide each team member's job. } \\
\text { 2. Make a schedule for the project. }\end{array}$ & $\begin{array}{l}\text { 1. Set a goal and main content for } \\
\text { the project. } \\
\text { 2. Make an effective plan. }\end{array}$ \\
\hline $\begin{array}{l}\text { Intensification of } \\
\text { Speaking Skills }(24 \\
\text { hours) }\end{array}$ & $\begin{array}{l}\text { 1. Learn model conversation. } \\
\text { 2. Practice listening and speaking. }\end{array}$ & $\begin{array}{l}\text { 1. Master related expressions and } \\
\text { sentences. } \\
\text { 2. Improve listening and speaking } \\
\text { skills. }\end{array}$ \\
\hline $\begin{array}{l}\text { Compiling of } \\
\text { Materials (16 hours) }\end{array}$ & $\begin{array}{l}\text { 1. Collect and select materials. } \\
\text { 2. Compile materials } \\
\text { 3. Write conversational text. } \\
\text { 4. Improve and finalize text. }\end{array}$ & $\begin{array}{l}\text { 1. Learn to select and categorize } \\
\text { materials. } \\
\text { 2. Learn to compile and write } \\
\text { conversational text. }\end{array}$ \\
\hline $\begin{array}{l}\text { Simulation } \\
\text { hours) }\end{array}$ & $\begin{array}{l}\text { 1. Learn, memorize and practice } \\
\text { conversation. } \\
\text { 2. Be inspected and improve } \\
\text { conversation under the guidance of } \\
\text { instructors. }\end{array}$ & $\begin{array}{l}\text { 1. Remember and master every } \\
\text { expression and sentence in the } \\
\text { conversation. } \\
\text { 2. Be able to perform the } \\
\text { conversation. }\end{array}$ \\
\hline $\begin{array}{lr}\text { Shooting } & \text { and } \\
\text { Production } & (24 \\
\text { hours }) & \\
\end{array}$ & $\begin{array}{l}\text { 1. Shoot conversational videos. } \\
\text { 2. Edit videos. }\end{array}$ & $\begin{array}{l}\text { 1. Be able to perform clear and } \\
\text { fluent Japanese conversation. } \\
\text { 2. Learn to use video editor. }\end{array}$ \\
\hline Display (8 hours) & $\begin{array}{l}\text { 1. Display the videos. } \\
\text { 2. Comment on the videos. }\end{array}$ & $\begin{array}{l}\text { 1. Learn how to display a project. } \\
\text { 2. Be able to summarize a project. }\end{array}$ \\
\hline
\end{tabular}

Assessment. The assessment consisted of formative assessment and final assessment as Table 2 shows.

Table 2 Assessment

\begin{tabular}{|l|l|l|l|}
\hline Category & Name & Content & Ratio \\
\hline \multirow{3}{*}{$\begin{array}{l}\text { Formative } \\
\text { Assessment }\end{array}$} & Attendance & $\begin{array}{l}\text { 1. Minus 2 points for absence at a time. } \\
\text { 2. Minus 1 point for being late, leaving early } \\
\text { or asking for leave at a time. }\end{array}$ & $20 \%$ \\
\cline { 2 - 4 } & Attitude & $\begin{array}{l}\text { Attitude includes: whether students are } \\
\text { active in the project; whether student raise } \\
\text { useful suggestions; whether students have } \\
\text { creative opinion. }\end{array}$ & $10 \%$ \\
\cline { 2 - 5 } & $\begin{array}{l}\text { Task } \\
\text { Completeness }\end{array}$ & $\begin{array}{l}\text { Task completeness means: whether students } \\
\text { accomplish assigned tasks; whether the } \\
\text { scorers are satisfied with their tasks. }\end{array}$ & $20 \%$ \\
\hline $\begin{array}{l}\text { Final } \\
\text { Assessment }\end{array}$ & $\begin{array}{l}\text { Overall } \\
\text { Assessment }\end{array}$ & $\begin{array}{l}\text { five aspects: pronunciation, correctness of } \\
\text { spoken language, content of conversation, } \\
\text { video making and related documents. }\end{array}$ & $\begin{array}{l}\text { (Each aspect } \\
\text { accounts for } \\
10 \%)\end{array}$ \\
\hline
\end{tabular}


Results of Project. The project SDJCS consolidated students' knowledge acquired in the first academic year and made them realize their weaknesses. By doing the project students could actively and creatively take part in it and meanwhile enhanced students' mutual communication, which in turn cultivate their team spirit and stimulate their future learning interest. By finishing different stage tasks students also learnt how to find out, analyze and solve problems on their own.

\section{Problems and Countermeasures}

Inadequate Awareness of Training Project. Not all students accept hands-on training and self-learning mode, and a few students even regarded the project as homework. Some works were not well prepared and done, so the training aim was not achieved. Besides, some teachers still held the opinion that it was better to make a change while it was the best not to make any change. [8] However, as pushers of education innovation, teachers and instructors should make themselves first accept new teaching theories and modes. Thus to stimulate students to treat the training project seriously, teachers should constantly emphasize the importance of active self-learning and cultivate students' awareness of "doing in learning and learning from doing".[9]

Inadequate Resources. Students generally said they could not produce better videos because of the lack of professional equipment. What's more, they could not get professional guidance when they had some troubles with editing. Thus it is suggested that Neusoft University should increase funds for teaching resources and employ more professional teachers who know video editing to provide more advice.

\section{Summary}

Applying the concept of CDIO into Japanese talents cultivation and integrating unconnected courses into a comprehensive and systematic training project, the Japanese education in Chendu Neusoft University effectively combined IT strengths of the university, language application and team spirits. What's more, the assessment mode combined communication with language skills, data handling, writing, behaviors and language environment, which is an effective assessment for multicultural communication.[10] This project not only strengthened the skills of Japanese language and computer application, but also effectively linked the previous and later courses, which embodied its step-by-step cultivation and systematic teaching. The introduction of this concept has brought a lot of benefits to Japanese talents cultivation.

\section{Reference}

[1] Pan Maoyuan, Che Rushan. On the Positioning of Application-Oriented Universities[J]. Journal of Higher Education, 2009, (5): 35-38.

[2] Gu Peihua, Shen Minfen, Lu Xiaohua. Rethinking Engineering Approach --- The CDIO Approach[M]. Beijing: Higher Education Press, 2009.

[3] Gu Peihua. From CDIO to EIP-CDIO: A Probe into the Mode of Talent Cultivation in Shantou University[J]. Research in Higher Education of Engineering, 2008, (1): 12-20.

[4] Vencenti, W. G., What Engineers Know and How It: Analytical Studies from Aeronautical History, The Johns Hopkins University Press, Baltimore, Maryland, 1990.

[5] Yang Wenming. The Connotation and Classification of Project Teaching[J]. Journal of Language and Literature Studies (Foreign Language Teaching), 2010, (7):87-89.

[6] Wang Lili. A Study on Employment-Oriented Applied Japanese Talent Cultivation[J]. Technology Wind 2017, (18): 251.

[7] Wen Tao. Explore and Construct the Integrated TOPCARES-CDIO Talent Training Mode[J]. China Higher Education, 2011, (7): 41.

[8] Rudolph, F. The American College and University: A History, The University of Georgia Press, Athens, Georgia, 1990. 
[9] John Dewey. The School and Society[M]. Zhao Xianglin, Ren Zhongyin, Wu Zhihong, translate. Beijing: Peoples Education Press, 1994: 252-253.

[10] Byram, M. Teaching and Assessing Intercultural Communicative Competence[M]. Clevedon: Multilingual Matters, 1997. 